\title{
Dietary habits and body weight status of Undergraduate Medical Students of Bangladesh and their Influence on Academic Performance
}

\author{
Brig Gen Dr. Md Aminul Islam Sikder', Dr. Kazi Khairul Alam², Professor Dr. Md Humayun Kabir Talukder ${ }^{3}$
}

\begin{abstract}
This cross sectional descriptive study was conducted to explore the dietary habits and body weight status of undergraduate medical students of Bangladesh and their influence on academic performance. The study period was from July 2017 to June 2018. The sample size was 907 . Medical colleges were selected purposively and convenience sampling technique was adopted for data collection. The study was carried out among the students of $3^{\text {rd }}$ and $4^{\text {th }}$ phase MBBS course of five public and three non-government medical colleges of Dhaka and outside Dhaka. Academic performance was determined by the results of professional examinations and class attendance. A self-administered structured questionnaire was used. Among the respondents medical students $330(36.5 \%)$ were males and $575(63.5 \%)$ were females. Descriptive statistics were used to identify the dietary practices of the students. Chi squared test and unpaired $t$ test were done to examine the influence of diets and BMI on academic performance. The study revealed that $535(59.9 \%)$ students took three main meals regularly. Breakfast was the commonest meal skipped among 230 (24\%) students altogether. Among the respondents students, 652 (73.2\%) took first class proteins daily, 398 (44.8\%) vegetables daily and only 85 ((9.6\%) students took fruits daily. 661 (74.4\%) of the students belonged to healthy BMI group and 73 (8.2\%) students were underweight, $12(1.4 \%)$ students were obese and $3(0.3 \%)$ were morbidly obese. Gender wise there was no significant difference of BMI.

The study further revealed that students who took first class protein daily had better performance in the professional examinations. Skipping of breakfast and consumption of vegetable and fruits did not affect students' academic performance. The students with healthy BMI had higher percentage in class attendance than the overweight students.

The study recommended that steps to be taken to implement healthy dietary practices among the medical students for positive influence on academic performance.
\end{abstract}

Keywords: Diets, BMI, Influence, Academic performance.

\section{Introduction}

A medical student's academic performance attracts the attention of all those involved in medical education. Moreover, the improvement of students' achievements has always been one of the main goals of education. Many studies were conducted to identify the factors that affect (positively or negatively) student achievement. Identifying those factors and the correlation between them is a very complex process.

University life is potentially important target for the promotion of healthy lifestyle of the young adult population. Nevertheless, medical students do not make an extra effort to choose a healthier lifestyle or to eat healthy food. Poor time

\section{Professor of surgery and advisor specialist Armed Forces Medical Institute, Dhaka Cantonment, Dhaka. \\ 2. Assistant Professor, Medical Education Centre for Medical Education, Mohakhali, Dhaka. \\ 3. Professor, Curriculum Development and Evaluation Centre for Medical Education, Mohakhali, Dhaka.}

Address of correspondence:

Brig Gen Dr. Md Aminul Islam Sikder

Professor of surgery and advisor specialist

Armed Forces Medical Institute, Dhaka Cantonment, Dhaka.

E-mail: dramindmc@gmail.com management is the most commonly cited factor preventing achievement of a healthier lifestyle among the medical students. Overall most medical students were aware of the importance of healthy eating habits yet they were not practicing it adequately in their daily life. ${ }^{2}$

College life is an important stage for individuals as at this time their behaviors are conducive to change. University and college arenas, therefore, represent an important opportunity for health and nutritional education. ${ }^{3}$

Although most of students are aware of the concept of nutritionally balanced food, only a small number of students apply this concept when selecting food from a menu. ${ }^{4}$

Few studies have investigated the independent associations of lifestyle behaviors like; diet, physical activity, and body weight status with academic achievement. Even fewer have investigated the combined effect of these behaviors on academic achievement. ${ }^{5}$ There has been no study on this issue in Bangladesh to focus on medical students' diet and body weight status and their relationship with the results of professional examinations and class attendance. Our aim is to investigate the effects of diets, dietary behaviors and BMI on academic performance. We hypothesize that these independent variables will have an effect on academic achievement.

Bangladesh Journal of Medical Education 2019;10(2):6-11. (C) 2019 Sikder et al., publisher and licensee Association for Medical Education. This is an Open Access article which permits unrestricted non-commercial use, provided the original work is properly cited. 


\section{Methodology}

It was a cross-sectional descriptive study, conducted in 08 purposively selected government and non-government medical colleges of Bangladesh.

Pre tested, self-administered, structured, English questionnaire were used for data collection. Fifty-seven items were included in the questionnaire. Total respondents were 961 , conveniently selected $3^{\text {rd }}$ and $4^{\text {th }}$ phase MBBS students. After collecting data, the questionnaire were checked for incomplete responses, inconsistency and missing data and coded. Fifty four questionnaire were excluded. Finally responses of 907 questionnaire were analyzed.

Collected data were entered into Statistical Package for Social Sciences (SPSS) version 19.0. Analyzed data were expressed as mean \pm standard deviation for numerical variables and as frequency and percentage for categorical variables. Association between independent and dependent variables were assessed by $\chi 2$ test and t test. Strength of relationship were considered significant if $p$ value is less than 0.05 . Data are presented by tables and graphs with descriptions and statistical analysis.

\section{Results}

Table 1: Distribution of the respondents medical students by their phase of study and gender

\begin{tabular}{lccc}
\hline & \multicolumn{2}{c}{ Gender the medical student } & \\
\cline { 2 - 3 } Phase of study & Male No. (\%) & Female No. (\%) & Total No. (\%) \\
\hline 3rd phase & $177(19.5)$ & $285(31.4)$ & $462(50.9)$ \\
4th phase & $153(16.9)$ & $292(32.2)$ & $445(49.1)$ \\
Total & $330(36.4)$ & $575(63.6)$ & $907(100)$ \\
\hline
\end{tabular}

Table 1 shows that out of 907 students, $50.9 \%$ were from $3^{\text {rd }}$ phase and $49.1 \%$ from $4^{\text {th }}$ phase. Among the students, $63.6 \%$ students were female.

Table 2: Distribution of the medical students by their BMI group and gender

\begin{tabular}{lcccc}
\hline \multirow{2}{*}{ BMI group } & \multicolumn{2}{l}{ Gender of medical student } & & \\
\cline { 2 - 4 } & $\begin{array}{c}\text { Male No. } \\
(\%)\end{array}$ & $\begin{array}{c}\text { Female } \\
\text { No. }(\%)\end{array}$ & $\begin{array}{c}\text { Total No. } \\
(\%)\end{array}$ & Statistics \\
\hline Underweight & $27(3.0)$ & $46(5.1)$ & $73(8.2)$ & \\
Healthy & $234(25.8)$ & $427(47.0)$ & $661(74.4)$ & $\chi^{2}=3.089$ \\
Overweight & $59(6.5)$ & $80(8.8)$ & $139(15.3)$ & $\mathrm{df}=3$ \\
Obese & $6(0.7)$ & $6(0.7)$ & $12(1.4)$ & $\mathrm{P}=0.378$ \\
Morbidly & $1(0.1)$ & $2(0.2)$ & $3(0.3)$ & \\
obese & $327(36.5)$ & $561(63.5)$ & $888(100.0)$ & \\
Total & & & & \\
\hline
\end{tabular}

Table 2 shows that among the medical students, 74.4\% belonged to healthy BMI group and $8.2 \%$ students were underweight, $1.4 \%$ students were obese and $0.3 \%$ were morbidly obese. Gender wise there was no significant difference of BMI $(\mathrm{P}=0.378)$

Figure 1: Distribution of students by their habit of skipping meals $(\mathrm{n}=898)$

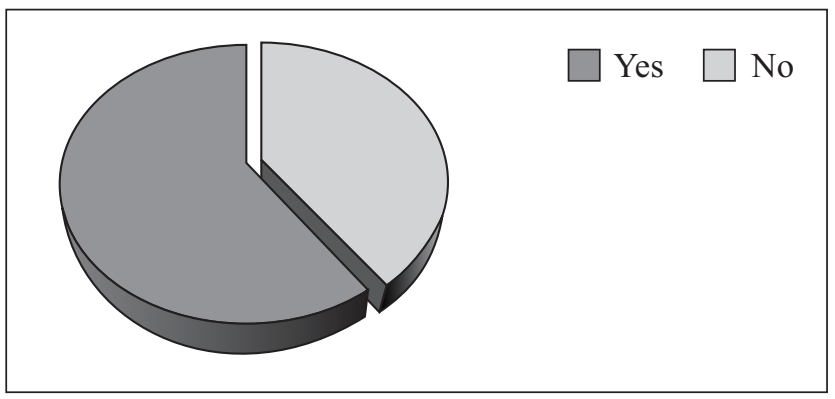

Figure 1 shows that $60 \%$ of the students took three main meals per day and $40 \%$ students skipped one of the main meals.

Table 3: Distribution of the respondents medical students by their habits of skipping meals and gender

\begin{tabular}{lcccc}
\hline \multirow{2}{*}{$\begin{array}{l}\text { Meals } \\
\text { skipped }\end{array}$} & $\begin{array}{c}\text { Male No. } \\
(\%)\end{array}$ & $\begin{array}{c}\text { Female } \\
\text { No. }(\%)\end{array}$ & $\begin{array}{c}\text { Total } \\
\text { No. }(\%)\end{array}$ & Statistics \\
\hline Breakfast & $103(44.8)$ & $127(55.2)$ & $230(100)$ & $\chi^{2}=32.851$ \\
Lunch & $6(42.9)$ & $8(57.1)$ & $14(100)$ & $\mathrm{df}=3$ \\
Dinner & $14(13.5)$ & $90(87.5)$ & $104(100)$ & $\mathrm{P}=0.000$ \\
Total & $124(35.5)$ & $225(64.5)$ & $349(100)$ & \\
\hline
\end{tabular}

Table 3 shows that out of 349 students who skipped one of the main meals, breakfast was the commonest meal skipped followed by dinner and lunch. Again number of female students skipping dinner was more than the male students. The differences in meal skipping between the respondents students were statistically significant $(\mathrm{P}=0.000)$.

Table 4: Distribution of respondents medical students by their food habits

\begin{tabular}{|c|c|c|c|c|c|c|}
\hline \multirow[b]{2}{*}{ Foods } & \multicolumn{6}{|c|}{ Number of days taking the food per week } \\
\hline & $\begin{array}{l}\text { Never } \\
\%\end{array}$ & $\begin{array}{l}1 \text { to } \\
2 \%\end{array}$ & $\begin{array}{l}3 \text { to } \\
4 \%\end{array}$ & $\begin{array}{l}5 \text { to } \\
6 \%\end{array}$ & $\begin{array}{l}\text { Daily } \\
\%\end{array}$ & Mean \pm SD \\
\hline $\begin{array}{l}1^{\text {st }} \text { class protein } \\
(\mathrm{n}=891)\end{array}$ & 0.2 & 2.2 & 11.4 & 12.9 & 73.2 & $6.29 \pm 1.373$ \\
\hline $\begin{array}{l}2^{\text {nd }} \text { class protein } \\
(\mathrm{n}=891)\end{array}$ & 2.7 & 19.1 & 23.9 & 12.6 & 41.8 & $4.72 \pm 2.297$ \\
\hline $\begin{array}{l}\text { Fat rich food } \\
(n=888)\end{array}$ & 8.4 & 70.9 & 15 & 3.2 & 2.5 & $1.76 \pm 1.435$ \\
\hline Fruits $(\mathrm{n}=887)$ & 14.2 & 49.7 & 20.3 & 6.2 & 9.6 & $2.36 \pm 2.056$ \\
\hline $\begin{array}{l}\text { Vegetables } \\
(\mathrm{n}=888)\end{array}$ & 4.5 & 16.9 & 21.7 & 12 & 44.8 & $4.82 \pm 2.346$ \\
\hline $\begin{array}{l}\text { Soft/energy drinks } \\
(\mathrm{n}=880)\end{array}$ & 26.7 & 53.1 & 15.1 & 2.7 & 2.4 & $1.59 \pm 1.89$ \\
\hline $\begin{array}{l}\text { Sweets/free sugar } \\
(\mathrm{n}=884)\end{array}$ & 0.2 & 2.2 & 11.4 & 12.9 & 73.2 & $2.21 \pm 2.05$ \\
\hline
\end{tabular}


Table 4 shows that majority of the students (73.2\%) regularly consumed first class protein, $44.8 \%$ took vegetables daily and only $9.6 \%$ of the students ate fruits every day. Among the respondents, only $2.5 \%$ students ate fat rich food daily and $26.7 \%$ of the students never took soft/ energy drinks.

Table 5: Comparing the students' meal skipping habits with their performance in profeesinal examinations $(\mathrm{n}=892)$

\begin{tabular}{lccc}
\hline Skipping of meal & $\begin{array}{c}\text { Passed in 1st } \\
\text { attempt } \\
(\mathrm{n}=645)\end{array}$ & $\begin{array}{c}\text { Needed more } \\
\text { than 1 attempts } \\
(\mathrm{n}=247)\end{array}$ & Statistics \\
\hline Yes $(\mathrm{n}=357,100 \%)$ & $70.6 \%$ & $29.4 \%$ & $\begin{array}{r}\chi^{2}=0.881 \\
(\mathrm{df}=1)\end{array}$ \\
No $(\mathrm{n}=535,100 \%)$ & $73.5 \%$ & $26.5 \%$ & $\begin{array}{c}\mathrm{P}=0.360 \\
\text { (two sided) }\end{array}$ \\
\hline
\end{tabular}

Table 5 showing no significant association between skipping of meals and professional examination.

Table 6: Comparing the students' dietary habits with their performanc in professional examination (863)

\begin{tabular}{|c|c|c|c|}
\hline Food & $\begin{array}{l}\text { Attept needed } \\
\text { for passing }\end{array}$ & mean \pm SD & Statistics \\
\hline \multirow[t]{2}{*}{ 1st class protein } & $\begin{array}{c}\text { 1st attempt } \\
(n=641)\end{array}$ & $6.36 \pm 1.316$ & $\mathrm{t}=2.279$ \\
\hline & $\begin{array}{c}>1 \text { attempts } \\
(\mathrm{n}=244)\end{array}$ & $6.11 \pm 1.482$ & $\begin{array}{c}\mathrm{P}=0.023^{*} \\
\text { (Two sided) }\end{array}$ \\
\hline \multirow[t]{2}{*}{2 nd class protein } & $\begin{array}{l}1 \text { st attempt } \\
(n=641)\end{array}$ & $4.68 \pm 2.297$ & $\mathrm{t}=-.946$ \\
\hline & $\begin{array}{c}>1 \text { attempts } \\
(\mathrm{n}=244)\end{array}$ & $4.85 \pm 2.300$ & $\begin{array}{c}\mathrm{P}=0.344 \\
\text { (Two sided) }\end{array}$ \\
\hline \multirow[t]{2}{*}{ Fat rich food } & $\begin{array}{l}\text { 1st attempt } \\
(n=638)\end{array}$ & $1.72 \pm 1.428$ & $\mathrm{t}=1.042$ \\
\hline & $\begin{array}{c}>1 \text { attempts } \\
(n=244)\end{array}$ & $1.83 \pm 1.437$ & $\begin{array}{c}\mathrm{P}=0.298 \\
\text { (Two sided) }\end{array}$ \\
\hline \multirow[t]{2}{*}{ Fruits } & $\begin{array}{l}\text { 1st attempt } \\
(\mathrm{n}=640)\end{array}$ & $2.36 \pm 2.095$ & $\mathrm{t}=2.038$ \\
\hline & $\begin{array}{c}>1 \text { attempts } \\
(\mathrm{n}=241)\end{array}$ & $2.36 \pm 1.949$ & $\begin{array}{c}\mathrm{P}=0.137 \\
\text { (Two sided) }\end{array}$ \\
\hline \multirow[t]{2}{*}{ Vegetables } & $\begin{array}{l}\text { 1st attempt } \\
(\mathrm{n}=641)\end{array}$ & $4.88 \pm 2.346$ & $\mathrm{t}=1.052$ \\
\hline & $\begin{array}{c}>1 \text { attempts } \\
(\mathrm{n}=241)\end{array}$ & $4.69 \pm 2.345$ & $\begin{array}{c}\mathrm{P}=0.664 \\
\text { (Two sided) }\end{array}$ \\
\hline \multirow[t]{2}{*}{$\begin{array}{l}\text { Soft/energy } \\
\text { drinks }\end{array}$} & $\begin{array}{l}\text { 1st attempt } \\
(n=633)\end{array}$ & $1.47 \pm 1.922$ & $\mathrm{t}=3.146$ \\
\hline & $\begin{array}{c}>1 \text { attempts } \\
(n=242)\end{array}$ & $1.90 \pm 1.748$ & $\begin{array}{c}\mathrm{P}=0.081 \\
\text { (Two sided) }\end{array}$ \\
\hline \multirow[t]{2}{*}{ Sweets } & $\begin{array}{l}\text { 1st attempt } \\
\quad(n=638)\end{array}$ & $2.16 \pm 2.052$ & $\mathrm{t}=1.178$ \\
\hline & $\begin{array}{c}1 \text { attempts } \\
(\mathrm{n}=244)\end{array}$ & $2.34 \pm 2.041$ & $\begin{array}{c}\mathrm{P}=0.513 \\
\text { (Two sided) }\end{array}$ \\
\hline
\end{tabular}

Table 6 shows that most of the students regularly consumed first class protein and many of the students took almost regularly second class protein and vegetables. There was significant difference $(\mathrm{P}=0.023)$ between times of protein intake and professional examination result. There were no association between intake of fruits and vegetables and academic performance.

Table 7: Comparing the students' BMI with their performance in the professional examinations

\begin{tabular}{|c|c|c|c|c|}
\hline \multicolumn{4}{|c|}{ Attempt for passing professional } & \multirow[t]{2}{*}{ Statistics } \\
\hline \multicolumn{4}{|c|}{1 st attempt 2 nd attempt $>2$ attempts } & \\
\hline Underweight & $69.9 \%$ & $26.0 \%$ & $4.1 \%$ & \multirow{3}{*}{$\begin{array}{c}\chi^{2}=.864, \\
d f=4 \\
P=0.930\end{array}$} \\
\hline $\begin{array}{l}\text { Healthy BMI } \\
\text { group }\end{array}$ & $71.9 \%$ & $24.6 \%$ & $3.5 \%$ & \\
\hline $\begin{array}{l}\text { Overweight, } \\
\text { obese \& } \\
\text { morbidly obese }\end{array}$ & $70.1 \%$ & $27.3 \%$ & $2.6 \%$ & \\
\hline
\end{tabular}

Table 7 shows that $71.9 \%$ students belonging to healthy BMI group passed $1^{\text {st }}$ professional examination at first attempt which is more than the overweight group (70.1\%). Which implies that, healthy student among BMI group gave better performance in the first attempt professional examinations. The relations were not statistically significant $(\mathrm{P}=0.930)$.

Table 8: Comparing the students' body mass index $(\mathrm{BMI})$ with their class attendance

\begin{tabular}{lcccc}
\hline & \multicolumn{3}{c}{ Class attendance } & \\
$\begin{array}{l}\text { Body mass index } \\
\text { (BMI) }\end{array}$ & & & & Statistics \\
\hline & $<60 \%$ & $60-75 \%$ & $>75 \%$ & \\
Underweight & $5.5 \%$ & $21.9 \%$ & $72.6 \%$ & $\chi^{2}=7.073$ \\
$\mathrm{df}=4$ \\
$\begin{array}{l}\text { Healthy BMI } \\
\text { group }\end{array}$ & $2.3 \%$ & $19.2 \%$ & $78.5 \%$ & $\mathrm{P}=0.132$ \\
$\begin{array}{l}\text { Overweight, obese } \\
\& \text { morbidly obese }\end{array}$ & $5.8 \%$ & $18.7 \%$ & $75.5 \%$ & \\
\hline
\end{tabular}

Table 8 shows that class attendance has been directly related to BMI groups. Among BMI group (Underweight, Healthy and Overweight) class attendance of healthy group percentage is higher $(78.5 \%)$ followed by overweight $(75.5 \%)$ and underweight group (72.6\%). Although, the healthy students among the BMI group gave better attendance performance but, there was no statistically significant difference among the class attendance categories $(\mathrm{P}=0.132)$. 
Table 9: Comparing the students' class attendance with their performance in professional examinations

\begin{tabular}{lcccc}
\hline & \multicolumn{3}{c}{$\begin{array}{c}\text { Attept for passing professional } \\
\text { examinations }\end{array}$} & \\
\cline { 2 - 3 } $\begin{array}{l}\text { Percentages of } \\
\text { class attendance }\end{array}$ & 1st attempt & 2nd attempt & $>2$ attempts & \\
\hline $\begin{array}{l}<60 \% \\
(\mathrm{n}=28,100 \%)\end{array}$ & $35.7 \%$ & $57.1 \%$ & $7.1 \%$ & \\
$\begin{array}{l}60 \text { to }<75 \% \\
(\mathrm{n}=177,100 \%)\end{array}$ & $58.8 \%$ & $35.6 \%$ & $5.6 \%$ & $\begin{array}{c}\chi^{2}=39.61 \\
\mathrm{df}=4\end{array}$ \\
$\begin{array}{l}\mathrm{P}=0.000 \\
(\mathrm{n}=701,100 \%)\end{array}$ & $76.2 \%$ & $21.1 \%$ & $2.7 \%$ & \\
\hline
\end{tabular}

Table 9 shows that, the students who had higher class attendance passed mostly at first attempt in the professional examinations. Students who had lowest percentage in class attendance usually required second or more attempts to pass. This finding was statistically highly significant $(\mathrm{P}=0.000)$.

\section{Discussion}

This was a cross sectional study carried out among $3^{\text {rd }}$ and $4^{\text {th }}$ phase MBBS students of selected medical colleges of Bangladesh both public and non-government, from Dhaka and outside Dhaka. Total 8 medical colleges were included in the study. Data were collected from the respondents using structured self- administered questionnaire.

Among the students $50.9 \%$ were from $3^{\text {rd }}$ phase and $49.1 \%$ from $4^{\text {th }}$ phase. In this study $36.5 \%$ respondents were male and $63.5 \%$ respondents were female. (Table 1 ). This finding is similar to the finding of Hossain $Z^{6}$ where in his study males were $37.11 \%$ and females were $62.9 \%$, very close to the findings of Garusi et al. ${ }^{7}$, but differs from a study conducted on medical students at a Saudi university by Mohammed et $\mathrm{al}^{8}{ }^{8}$ where $64 \%$ of the students were males. This increase number of female students in the present study may be due to their better results in secondary and higher secondary levels reflecting the number of female students in higher education.

Most of the students of this study (74.4\%) belonged to the healthy BMI group (BMI 20-25). 5\% male and $8.8 \%$ female students were overweight (BMI 25-30) and 3\% of male students and $5.1 \%$ of female students were in underweight group (BMI <20), obese group (BMI 30-35) included only $1.4 \%$ of the students (Table 2 ). This finding are very close to the finding of Garusi et al. ${ }^{7}$ done in Tehran university medical students but differs from a study among Chinese medical students from Beijing University by Sakamaki et al, ${ }^{4}$ where only $2.5 \%$ students were overweight and $0.4 \%$ were obese (BMI $>30)$ which are lower than the present study. In another study by Schmidt ${ }^{9}$ done in Sweden among university students, where altogether $73.7 \%$ of the participants had normal weight, very much similar to our study. This trend of increasing number of overweight students are likely due to the effects of sitting with social media, and eating fast food.

Regarding eating habits, the results of our study showed that $40 \%$ of the students regularly skip one of the three main meals of the day (Figure 1). Among the respondents skipping one of the main meals, breakfast was the most commonly missed meal (66\%) followed by dinner $(30 \%)$ and lunch (4\%) (Table 3). Altogether 24\% students used to skip breakfast. As for intake of chicken, fish, meat or egg, in this study $73.2 \%$ reported that they consumed $1^{\text {st }}$ class protein daily and 44.85 students took vegetables daily and only $9.6 \%$ students ate fruits daily (Table 4 ).

As per the number of meals per day, protein and vegetables intake, findings of this study is consistent with the study of Sakamaki et al. ${ }^{4}$, Sajwani et al. ${ }^{10}$ and Al-Nagger et al. ${ }^{11}$ but differs much on amount of fruits intake in the present study. Johansen et al. ${ }^{12}$ demonstrated in their study in Denmark showing $26 \%$ of the students did not eat breakfast every day, very much similar to our observation. Findings of this study are not consistent to the study conducted by Lupi ${ }^{13}$ where only a small group (8\%) students said they skip breakfast. Skipping of meals among the students of current study is likely due to poor time management, lack of accessibility, food choices or weight control program.

As regard influence of dietary habits on academic performance, many of the behaviours had positive influence on academic performance but some of the habits had no relation at all. In our study, about $40 \%$ students skipped regularly any one of the main meals. Breakfast was the most commonly missed meal in $24 \%$ cases all together. Present study demonstrated that $73.5 \%$ of the students who did not skip any of the meals passed professional examination in first chance as compared to $70.6 \%$ who skipped any one of the meals, the association is not significant ( $\mathrm{P}=0.360$ ) (Table 5). The study by Mickey et al. ${ }^{14}$ also found relationship between eating breakfast and academic performance. This was probably partially a result of collinear sleeping habits, students have to get up earlier if they intend to eat breakfast. They might also attend the morning lectures and therefore contributing to better results.

Regarding dietary intake and academic performance, in our study, there was a significant statistical relationship between dietary intake of first class protein like meat, chicken, fish, eggs etc. and participants' result of professional examination $(\mathrm{P}=0.023)$ (Table 6). Our results were in accordance with Abd-El-kader et al. ${ }^{15}$ demonstrating a significant statistical difference between the dietary intake $\&$ academic score of participants regarding taken of animals meat, poultry, milk, fish, egg, vegetables, fruit, soft drinks as well as starchy foods. A Canadian study with the objective of investigating the effects of meeting recommendations for diets among school children found positive associations with academic achievements. ${ }^{5}$

As regards association between BMI and academic performance, this study demonstrated that students with healthy BMI did no better in the professional examinations (Table 7). But had better percentage in class attendance than the overweight participants (Table 8). This finding is similar to the finding of Alswat KA et al. ${ }^{16}$ showing no correlation between the BMI and academic performance. 
Class attendance is considered a performance in our study. Again it is an independent variable for the professional examinations. We analyzed their relationships. Present study revealed that class attendance had a significant positive association $(\mathrm{P}=0.000)$ (Table 9) with the results of professional examinations. Lukkarinena et al. ${ }^{17}$ concluded that attendance is positively and significantly related to performance, after controlling for the effect of other variables potentially related to performance.

This study had many limitations. Purposive selection of the medical colleges was a methodical limitation. Confounders like parental income, education and students' motivation were not adjusted. Reliance on self-responded structured questionnaire was another limitation, respondents might read the questions differently. Because of the cross sectional design of the study, conclusions regarding the causality of the observed relationship cannot be drawn.

\section{Conclusion}

The improvement of academic achievement is one of the main goals of education. Moreover, it has become a key to student's future.

This cross sectional study investigated the influence of diets and dietary habits and BMI on academic performance of third and fourth phase MBBS students of selected medical colleges of Bangladesh. There were a significant relationship between participants' daily intake of first class protein and academic performance. Students' BMI had no effect on results of professional examinations but influenced percentage of class attendance. In turn, class attendance had significant association with the results of professional examinations. On the other hand, some dietary factors like habits of skipping breakfast, eating fruits and vegetable had no relationship with the students' academic results.

It is recommended to initiate health programs at institute level in the medical colleges to raise student awareness and motivate practice of healthy dietary behavior. Further large scale study on randomly selected samples are needed to generalize the study findings and to analyze more closely these associations.

\section{References}

1. Shawwa LA, Abulaban AA, Abulaban AA, Merdad A, Baghlaf S, Algethami A, Abu-shanab, J \& Balkhoyor A (2015). Factors potentially influencing academic performance among medical students, Advances in Medical Education and Practice; 6: 65-75.

2. Alissa EM, Alsawadi H, Zedan A, Alqarni D, Bakry M \& Hli BN. (2015). Knowledge, Attitude and Practice of Dietary and Lifestyle Habits Among Medical Students in King Abdulaziz University, Saudi Arabia, International Journal of Nutrition and Food Sciences;Vol. 4: No. 6, pp. 650-655.

3. Webb E, Ashton CH, Kelly P \& Kemali F. (1998). An update on British medical students' lifestyles. Med Educ; 32:325-31.

4. Sakamaki, R, Toyama, K, Amamoto, R. (2005). Nutritional knowledge, food habits and health attitude of Chinese university students -a cross sectional study, Nutritional Journal; 4:4.

5. Faught EL, Ekwaru JP, Gleddie D, Storey KE, Asbridge M and Veugelers PJ, 2017. The combined impact of diet, physical activity, sleep and screen time on academic achievement: a prospective study of elementary school students in Nova Scotia, Canada, International Journal of Behavioral Nutrition and Physical Activity, 14:29.

6. Hossain Z. (2017). Activities Reducing Stress among Undergraduate Medical Students of Selected Medical colleges of Bangladesh: Teachers' and Students' perception, MMEd thesis, Centre for Medical Education, Dhaka, Bangladesh.

7. Garrusi B, Safizadeh H, Pourchosseini O. (2008). A Study on the Lifestyle of the Iranian University Students, Iranian Journal of Psychiatry and Behavioral Sciences; vol.2, no. 2 .

8. Mohammed OS, Alyoussef AA, Mirghani HO, Ahmed MA \& Elbadawi AS. (2015). Impact of Lifestyle on Academic Performance of Medical Students at University of Tabuk, Indian Journal of Applied Research; Vol:5, Issue:7.

9. Schmidt M. (2012). Predictors of Self-Rated Health and Lifestyle Behaviours in Swedish University Students, Global Journal of Health Science; vol. 4, no. 4.

10. Sajwani RA, Shoukat S, Raza R, Sheikh MM \& Rashid Q. (2009). Knowledge and practice of healthy lifestyle and dietary habits in medical and non-medical students of Karachi, Pakistan, Journal of the Pakistan Medical Association; 59(9): 650-5.

11. Al-Naggar RA, Bobryshev YV \& Mohd Noor NAB. (2013). Lifestyle Practice among Malaysian University Students, Asian Pacific J Cancer Prev; 14 (3), 18951903.

12. Johansen A, Rasmussen S \& Madsen M. (2006). Health behavior among adolescents in Denmark: Influence of school class and individual risk factors, Scand J Publ Health; 34(2):32-40.

13. Lupi S, Bagordo F, Stefanati A, Grassi T, Piccinni L, Bergamini $M$ \& Donno AD. (2015). Assessment of lifestyle and eating habits among $\mathrm{u}$ ndergraduate students in northern Italy,Ann Ist $\mathrm{Su}$ per Sanità; vol. 51, no. 2, pp. 154-161.

14. Mickey TT, Michael DB and Dennes LE. (2017). Health-Related Variables and Academic Performance among First-year College Students: Implications for Sleep and Other Behaviours, Journal of American College Health; 49:3,125-131. 
15. Abd-El-Kader MO \& Fathia AM. (2013). The Relationship between Lifestyle, General Health \& Academic Scores of Nursing Students, Public Health Research; 3(3): 54-70.

16. Alswat KA, Al-shehri DA, Aljuaid TA, Alzaidi BA, Alasmari HD, 2017. The association between body mass index and academic performance, Saudi Med J; Vol. 38 (2).
17. Lukkarinena A, Koivukangasa $P$ and Seppäläa $T$. (2016). Relationship between class attendance and student performance, Social and Behavioral Sciences; 228: 341-347. 